IZA DP No. 5427

Enrolment in Micro Life and Health Insurance:

Evidences from Sri Lanka

Mirko Bendig

Thankom Arun

January 2011

Forschungsinstitut zur Zukunft der Arbeit Institute for the Study of Labor 


\title{
Enrolment in Micro Life and Health Insurance: Evidences from Sri Lanka
}

\author{
Mirko Bendig \\ University of Göttingen \\ and GIGA \\ Thankom Arun \\ University of Central Lancashire, \\ University of Manchester and IZA
}

\author{
Discussion Paper No. 5427 \\ January 2011
}

IZA

P.O. Box 7240

53072 Bonn

Germany

Phone: +49-228-3894-0

Fax: +49-228-3894-180

E-mail: iza@iza.org

\begin{abstract}
Any opinions expressed here are those of the author(s) and not those of IZA. Research published in this series may include views on policy, but the institute itself takes no institutional policy positions.

The Institute for the Study of Labor (IZA) in Bonn is a local and virtual international research center and a place of communication between science, politics and business. IZA is an independent nonprofit organization supported by Deutsche Post Foundation. The center is associated with the University of Bonn and offers a stimulating research environment through its international network, workshops and conferences, data service, project support, research visits and doctoral program. IZA engages in (i) original and internationally competitive research in all fields of labor economics, (ii) development of policy concepts, and (iii) dissemination of research results and concepts to the interested public.
\end{abstract}

IZA Discussion Papers often represent preliminary work and are circulated to encourage discussion. Citation of such a paper should account for its provisional character. A revised version may be available directly from the author. 
IZA Discussion Paper No. 5427

January 2011

\section{ABSTRACT \\ Enrolment in Micro Life and Health Insurance: Evidences from Sri Lanka ${ }^{*}$}

Microinsurance is an emerging concept protecting households from the potentially catastrophic expenditures associated with family related shocks. Therefore, this paper presents evidence on the determinants of insurance participation using probit models on household survey data from Sri Lanka, conditional on household's microfinance institution enrolment. Further, we employ multivariate probit regressions to analyse factors affecting the participation in different types of insurance. We find that the household's experience of a family related shock is positively associated with the participation in micro health insurance schemes under study. There is strong evidence that microinsurance has not yet succeeded in proportionately reaching the most vulnerable households. Notably, education of the household head is a strong determinant of microinsurance participation.

JEL Classification: $\quad$ G22, O16, R22

Keywords: microinsurance, household behaviour, Sri Lanka

Corresponding author:

Thankom Arun

Lancashire Business School

Faculty of Management

University of Central Lancashire

Preston, Lancashire PR1 2HE

United Kingdom

E-mail: tgarun@uclan.ac.uk

\footnotetext{
* The financial support for the research underlying this paper for Sri Lanka was provided by the British Academy (SG-44036). We gratefully acknowledge to the Institute of Policy Studies, Sri Lanka for the field work and data collection and the helpful comments from Stephan Klasen, several other colleagues at the University of Göttingen, University of Manchester and the University of Central Lancashire. All errors are our own.
} 


\section{Introduction}

Few recent ideas have generated as much hope for alleviating poverty of poor households in developing countries as the idea of microfinance. In recent years, microfinance has grown and become more and more diversified due to a higher demand-orientation. Taking the demand of low-income groups into consideration has led the microfinance industry to diversify its savings and recently its insurance products (Zeller and Sharma 2002, Armendáriz and Morduch 2005, Bendig et al. 2009). The evolution of microinsurance out of microfinance promises the prospect of reducing the vulnerability of poor people to negative shocks and their consequences on income and consumption.

The type of risks faced by the poor such as that of death, illness, injury and accident, are no different from those faced by others, but they are indeed more exposed to such risks that can severely affect their livelihoods due to their economic status, income and earning abilities (Holzmann and Joergensen 2000, Siegel et al. 2001). A household can cope with risk at two stages, ex ante and ex post of the occurrence of such shock (Morduch 1995, Townsend 1995, Kazianga and Udry 2006). First, households can smooth income by diversifying economic activities and choosing conservative production or employment activities to prevent the households from the consequences of shocks before they occur. Second, households can smooth consumption by borrowing, saving, depleting and accumulating non-financial assets, changing labour supply, using formal and informal insurance arrangements to mitigate the consequences after the incidence of a shock. Therefore, the availability of sufficient and efficient risk management strategies are widely seen as an important integral to any poverty reduction strategy. In the past, insurance was not considered to be an option for low-income groups as an ex ante risk management strategy, as they were seen too poor to afford insurance premiums and as well as uninsurable to the wide variety of risks they face (Siegel et al. 2001).

Microinsurance is defined as the 'protection of low-income people against specific perils in exchange for regular premium payments proportionate to the likelihood and cost of the risk involved' (Churchill 2006: 12). Using risk pooling in return for regular affordable premium payments proportionate to the likelihood and cost of the risk involved, microinsurance policies respond to the limited and variable cash flow of low-income households, and the often unstable economic environment in which they live. As their resources are so limited, poor people can experience great financial disruption when unexpected events befall them so that even small sums insured can provide some protection and function as a preventive risk management opportunity. Another motive for the provision of microinsurance is that insurance markets in the world and especially in developing countries are still incomplete and that low-income households have been 
excluded from existing insurance schemes. On the one hand, there exists to some extent an unmet demand for insurance among the low-income groups, as they face many risks, do not have access to or not the abilities and empowerment to enter the formal insurance markets and on the other hand, formal insurers are not interested in that market segment which is outside the mainstream formal economy. As a result, they depend highly on traditional informal risk management mechanisms and public social security systems which are very costly and mostly insufficient to smooth consumption perfectly (Siegel et al. 2001).

Various contributions exists so far on the demand for informal insurance in developing countries (Townsend 1995, Morduch 1995, Dercon 2002, Fafchamps and Lund 2003), whereas studies on the demand for formal insurance are rarely spread in the literature ${ }^{2}$. None of the studies emphasizes different sequential steps of the household's insurance participation decision. Therefore, we estimate conditional probit models that account for the first two steps of the insurance participation decision. First, we investigate what determines the enrolment of a household in a microfinance institution (MFI) and by doing so control for household's access to the microfinance market. Second, we identify the determinants of household's insurance participation conditional on household's membership in a MFI. Finally, we employ multivariate probit regressions to estimate what determines household's decision to uptake different types of insurance, i.e. life, health and any other type of insurance. This empirical evidence is based on a comprehensive household survey of 330 households from Sri Lanka. We examine household's microinsurance participation, i.e. the usage of microinsurance, whereas the use of insurance, i.e. the actual provision, is determined by the demand and the supply of insurance (Worldbank, 2008: $28)^{3}$. Thereby, we emphasize primarily life and health insurance and focus on voluntary insurance offers $^{4}$.

The outline of the paper is as follows: Section 2 discusses the conceptual framework and the theoretical and empirical determinants of microinsurance participation in the literature. Section 3 presents an overview of the microinsurance market and risk exposure in Sri Lanka, the research design and estimation methodology. The results of the estimations are discussed in Section 4. Section 5 concludes.

\footnotetext{
2 The paper is related to another thread of literature, i.e. the growing literature emphasizing the household's ability to draw on their savings or entrance in informal risk sharing arrangements to smooth consumption. Various empirical studies show that households are able to protect consumption against certain income risks in developing countries, but not to achieve full insurance so far (See Townsend 1994, Kurosaki and Fafchamps 2002, Fafchamps and Lund 2003, for example). We cannot provide a full review of this extensive literature here.

${ }^{3}$ Whereas participation is determined by the demand and the supply of insurance (Worldbank, 2008: 28), we actually do not estimate the determinants of insurance demand, but the determinants of their actual provision, as non-insured households can be excluded voluntarily or involuntarily for a variety of reasons from the insurance markets. We interpret the estimation results concerning the usage of microinsurance, i.e. the access to insurance on the supply side and as well the demand side for microinsurance.

${ }_{4}$ Demand research across many countries repeatedly identifies illness and death risks as the primary concern of most low-income households Further, compulsory insurance products such as credit life insurances, which are typically bounded to the uptake of a loan or any other financial product, are dropped from the analysis.
} 


\section{A Conceptual Framework of Microinsurance Participation}

The contributions on insurance participation in developing countries are rarely discussed in the literature except from various studies on informal insurance in developing countries (Townsend 1995, Morduch 1995, 1999, Dercon 2002, Churchill 2006). By looking at the literature on the uptake of financial services, there are considerably more studies discussing especially the issue of credit than of insurance participation in developing countries (Bendig et al. 2009). Though, there are so far only few studies using quantitative data from household surveys to identify and analyze determinants of formal insurance participation (Asfaw 2003, Bendig et al. 2009, Bhat and Jain 2006, Cole et al. 2009, Giné et al. 2008, Giné and Yang 2009, Ito and Kono 2010, Jütting 2003), whereas the insurance examined are various in type such as health, life and rainfall insurance.

In a simple setting Giné et al. (2008) consider a model of insurance participation with symmetric information, which predicts that a household's willingness to pay for an insurance contract (i) increases if the household is more risk averse, (ii) increases with the expected insurance payout, (iii) increases with the size of the insured risks and (iv) decreases with basis risk $^{5}$. However, it is obvious that many households remain uninsured against significant income risks due to various reasons. Deviating from the above described full-information simple model, adverse selection and moral hazard are largely considered as potential explanations for barriers to insurance participation (Cawley and Phillipson 1999, Rothschild and Stiglitz 1976). Providing insurance has all the incentive problems related to the provision of credit (Rothschild and Stiglitz 1976, Browne and Doerpinghaus 1993, Pauly 2004, Armendáriz and Morduch 2005). Models of adverse selection and moral hazard are applicable to the life and health insurance contracts studied here. In the case of micro life insurances, the insurance providing institution cannot fully observe if an individual is at high or low risk of death. Though, the national life expectancy and health status is public information, but to observe these individually required a high and not efficient effort of time, costs and human resources. Therefore, adverse selection may be a problem in the insurance market. It is evident that this leads to problems in the insurance participation practice. Moral hazard may exist as well in a setting of insurance markets, if the household may live with less caution and risk more after contracting insurance, which is a major problem especially for health, but as well life insurances. In the case of micro health insurance, there is evidence for the existence of adverse selection, as households having a higher ratio of sick members are more likely to purchase micro health insurance (Ito and Kono 2010). Adverse

\footnotetext{
${ }^{5}$ I.e. increases in the correlation between the insurance payout and the risk to be insured, or more generally, the household's consumption risk (Giné et al. 2008). Cole et al. 2009 use the model as a benchmark. We can not control for the prediction in relation to the basis risks, as our data set does not include any index based insurances.
} 
selection seems one reason in combination with mistrust in the providers and unfamiliarity with insurance for low take-up rates, high claim rates and low renewal rates, so the providers are faced by difficult challenges to control for the incentive problems and simultaneously to educate the poor. Incentive structures such as solidarity enhancing rules seem to keep individual interests restrained by the group interests, whereas co-payment rules may be a strong deterrent to very poor households (Hamid et al. 2010).

In addition, it is important to assess the validity of arguments emerging from existing theoretical work on the demand for life insurance. Lewis (1989) was the first who explicitly includes the preferences of the dependents and beneficiaries into the model to extend the theoretical framework beyond previous work. He suggests the demand for life insurance not only as a maximization of the consumer lifetime utility, but as well as a maximization problem of beneficiaries, the spouse and the offspring of the life insurance policy holder, so life insurance should be purchased to satisfy the needs of survivors. The household's willingness-to-pay for life insurance will be (i) increasing with the probability of the breadwinner's death, (ii) increasing with the degree of risk aversion, (iii) increasing with the present value of the beneficiaries' consumption, (iv) decreasing with the policy loading factor and (v) decreasing with the household's wealth (Lewis 1989).

In a developed country context, there is evidence that individuals without life insurance are significantly less risk averse than their counterparts with life insurance, whereas the risk aversion increases with the income and wealth up to a mean of the respective distribution, and then decreases (Barsky et al. 1997). This indicates a life-cycle effect of the degree of an individual's risk aversion. It is plausible to propose that better off households have a higher ability and willingness to bear a given amount of risk compared to relatively poor households. For developing countries, there is evidence that risk averse households are less likely to purchase insurance (Giné et al. 2008) and that households who feel themselves more exposed to risk are less likely to use financial services and to use life insurance (Bendig et al. 2009). In respect to this, it may be the fact that risky households, i.e. the households who feel themselves more exposed to risk, have a lower access to insurance. By development theorists the poor are assumed to be the most risk averse (Ray 1999). The poor are too close to subsistence, so that a given loss can be ruinous for the poor in developing countries (Ray 1999). In respect to this, we suggest that microinsurance participation of low-income households increases with the degree of risk aversion in Sri Lanka.

With the level of income, life insurance participation may increase, as consumption and human capital increases with a higher level of income, i.e. creates a higher demand for mortality coverage to preserve income and consumption of household head and dependents. Lewis (1989), 
Truett and Truett (1990), Browne and Kim (1993) and Outreville (1996) have shown that the use of life insurance is positively related to income using individual household data both in a developed and developing country context. Beyond life insurance (Giné et al. 2008) and especially health insurance (Jütting 2003, Pauly 2004, Bhat and Jain 2006, Dror et al. 2007), it is evident for developing countries that households are more likely to uptake insurance with increasing income or wealth of the household. Chankova et al. (2008) find no evidence that individuals from the poorest quintiles are more likely to be excluded from mutual health organizations. Evidence for Bangladesh suggests that micro health insurance placement has only significant beneficial effect on food sufficiency, but not to other poverty indicators (Hamid et al. (2010).

Due the theoretical work of Lewis (1989), we assume that the present value of the beneficiaries' consumption may increase with the number of dependents within the household, whereas a higher number of young dependents increase the demand for mortality coverage and a higher number of old dependents the demand for savings through life insurance. If the households value bequest motives, we assume that household's micro life insurance participation increases with the number of dependents, especially young dependents, and the marital status "being married" due to intended bequest motives using a "joy-of-giving" motive (Hurd 1987, Hurd 1994, Inkmann and Michaelides 2010). Browne and Kim (1993) find as well that a dependency ratio variable and life insurance is positively correlated with life insurance consumption. Dror et al. (2007) find that household size is the most important determinant of willingness to pay for micro health insurance, so the households prefer to insure not only the main breadwinner, but as well the entire household.

Education may as well have an increasing effect on the time period of dependency, which may increase the demand for mortality coverage. A higher level of education is assumed to be positively correlated with the purchase of any type of life insurance product, as it may raise the ability to understand the benefits of risk management and savings, but as well increase individual's risk aversion (Beck and Webb 2002). An often identified constraint in selling insurance to poor households in developing countries is a lack of understanding of insurance products and the differences in their cognitive ability to understand such products (McCord 2001). Further, more educated households are more likely to take up insurance (Chankova et al. 2008, Giné et al. 2008). Therefore, we assume that more educated household heads are more likely to understand such a product more easily, and be more likely to participate in such insurance scheme than their less educated counterparts. In the case of micro health insurance, the poor may as well not only understand the concept fully, but as well their medical knowledge is scarce, and it is difficult for them to understand what is and is not covered under the policy 
(Chankova et al. 2008, Ito and Kono 2010). However, there is evidence that households have only a limited understanding of insurance and respectively risk management products and that factors according to financial literacy have a significant impact on the insurance participation decision (Cole et al. 2009). Another significant factor determining life insurance participation (Browne and Kim 1993, Arun and Bendig 2010b) may be religious inclination. Further, there exists an impact of the exposure of shocks on the usage of financial services, but it differs for the tested risks and financial services (Bendig et al. 2009, Arun and Bendig 2010a, Arun and Bendig 2010b).

\section{Market Overview, Research Design and Methodology}

\section{a) Sources of Data, Definition of Variables and Summary Statistics}

The data for this study comes from a household survey conducted in Sri Lanka in 2008. The survey was undertaken as a research project on the demand for microinsurance among lowincome households in Sri Lanka and respectively South Asia ${ }^{6}$.

In Sri Lanka, the study site covered 30 villages in all 14 districts of all regions. Five different MFIs, namely Women's Development Federation, Women's Development Banking Federation, Sanasa Insurance Company, Yasiru Mutual Fund and SEEDS (Sarvodaya Economic Enterprises Development Services Ltd) had been identified as the main suppliers of voluntary ${ }^{7}$ microinsurance for low-income households in Sri Lanka. The survey sampling frame is a census of households randomly selected from the client bases of the five respective MFIs and allocated among the districts in which the MFIs are operating. From each district, two or three of the respective MFIs have been chosen except from Vavunia and Batticaloa, which are in the Northern and Eastern provinces, where only SEEDS is operating. The selected number of households from each district differs from 15 to 50 households. Two or three villages from each district and one Community Based Organization (CBO) from each village are randomly picked representing the selected MFIs from each district. A total of $30 \mathrm{CBOs}$ are included in the survey with 10 to 15 clients each selected randomly from the client base. Half of these clients are insured and the other half is non-insured. In the case of Yasiru Mutual Fund all clients are insured, so that the non-insured clients were randomly chosen from the non-insured households in the villages, in which the insured clients of the Yasiru Mutual fund are located. In total 330 households were interviewed, including two strata of (micro) insured and non-insured households, whereas 240 households use and 90 do not use any insurance, including insurances

\footnotetext{
6 Additional specific objectives of the individual country study and household sample selection are described in greater detail elsewhere See Arun and Bendig 2010a, Arun and Bendig 2010b.

7 The participating institutions provide credit insurances as well, which are compulsory for the uptake of a loan or other financial product. Yet, these credit insurances are neglected in this analysis and the respective observations are dropped from the data set.
} 
offered by other institutions than the five respective MFIs. 304 households of the participating household heads are member of a MFI and/or use at least any financial services from them, i.e. all 240 insured households are MFI members. Among the insured clients, 142 households purchased a life insurance, 29 households a health insurance and 79 households among all insurance buying households purchased another type of insurance, for instance vehicle insurance ${ }^{8}$.

The data collection based on household characteristics questionnaires. The survey questionnaire contained detailed sections on demographic and socioeconomic household characteristics, household assets, the occurrence of shocks, risk management strategies, evaluation of household's risk self-assessment and situation. Special focus lies on information about the embedding of households in financial market, i.e. the integration in different financial institutions, and the use of financial services. The vector of explanatory variables includes different household characteristics including demographic and wealth variables, education, economic activities of the household head, information about remittances, a risk self-assessment index as a continuous variable, risk exposure dummies and regional dummies?.

Table 1 provides the summary statistics. The proportion of female households is higher among insurance non-buyers than among insurance buyers, while only $17 \%$ of the households are female-headed. Insurance buyers live in larger households and among them are slightly more married household heads than among non-buyers. The ratio of ill household members is significantly higher among participants than non-participants. Insurance buyers are significantly older than insurance non-buyers. Among the insurance buyers, the households owns more land, have more remittance receivers, a lower share of no, primary or secondary educated household heads and a lower share of self-employed household heads than among the insurance nonbuyers. In Sri Lanka, insurance buyers belong to wealthier households compared with nonbuyers $^{10}$. The households with insurance purchase have a significantly higher risk assessment

\footnotetext{
${ }^{8}$ Important to note that the use of insurance is as well not exclusive.

9 Table 4 (in Appendix) summarizes the definition of the variables in the estimations. To test for potential problems of multicollinearity, we computed the pairwise correlations between the explanatory variables. For the correlation matrix of the explanatory variables, we see no reason for concern. We calculated variance inflation factors (VIFs) to test for possible collinearity among independent variables, but found no substantial collinearity. We calculated the variance inflation factors using the collin command in Stata. Except for the regressors "age" and "age squared" all VIFs were less than 2.38 for the survey data (Specification II: 2.58) for Sri Lanka. We see no reason for concern as none of the variance inflation factors was higher than 2.58 . 10 To avoid potential endogeneity problems, we constructed an asset index, which is controlled for that none of the financial services contracted are used to purchase any asset. Economic status quintiles were assigned at the household level using the asset endowment index. reflects household's distribution among quintiles.
} 
index in Sri Lanka ${ }^{11}$. A higher share of insurance buyers experienced a severe illness of a household member than non-buyers.

Table 1: Summary Statistics Insurance Buyers and Non-Buyers in Sri Lanka

\begin{tabular}{|c|c|c|c|c|c|c|}
\hline \multirow[t]{2}{*}{ Variable } & \multicolumn{2}{|c|}{ Full Sample } & \multicolumn{2}{|c|}{ Insurance Buyers } & \multicolumn{2}{|c|}{ Insurance Non-Buyers } \\
\hline & Mean & Std. error & Mean & Std. error & Mean & Std. error \\
\hline Female head & 0.169 & 0.021 & 0.163 & 0.024 & 0.189 & 0.041 \\
\hline Household size & 4.094 & 0.078 & 4.204 & 0.091 & 3.8 & 0.147 \\
\hline Married head & 0.861 & 0.019 & 0.871 & 0.022 & 0.833 & 0.039 \\
\hline Ratio of ill household members & 0.393 & 0.023 & 0.409 & 0.027 & 0.349 & 0.042 \\
\hline Age & 47.88 & 0.644 & 47.41 & 0.744 & 49.12 & 1.280 \\
\hline Age squared & 2428.7 & 64.5 & 2379.9 & 73.2 & 2558.8 & 132.9 \\
\hline No or primary education & 0.191 & 0.021 & 0.171 & 0.024 & 0.244 & 0.046 \\
\hline Secondary education & 0.409 & 0.027 & 0.40 & 0.032 & 0.433 & 0.053 \\
\hline Head is selfemployed & 0.594 & 0.027 & 0.579 & 0.032 & 0.633 & 0.051 \\
\hline Head is unemployed & 0.221 & 0.023 & 0.221 & 0.027 & 0.222 & 0.044 \\
\hline Asset index & $-1.9 \mathrm{e}-09$ & 0.055 & 0.126 & 0.064 & -0.337 & 0.102 \\
\hline Quintile 1 & 0.2 & 0.022 & 0.167 & 0.024 & 0.289 & 0.048 \\
\hline Quintile 2 & 0.2 & 0.022 & 0.179 & 0.025 & 0.256 & 0.046 \\
\hline Quintile 3 & 0.2 & 0.022 & 0.2 & 0.026 & 0.2 & 0.042 \\
\hline Quintile 4 & 0.2 & 0.022 & 0.221 & 0.027 & 0.144 & 0.037 \\
\hline Land ownership & 0.773 & 0.023 & 0.825 & 0.025 & 0.633 & 0.051 \\
\hline Remittance & 0.052 & 0.012 & 0.054 & 0.015 & 0.044 & 0.022 \\
\hline Risk assessment & $9.9 \mathrm{e}-09$ & 0.168 & 0.009 & 0.067 & -0.025 & 0.093 \\
\hline Experienced death & 0.073 & 0.014 & 0.071 & 0.017 & 0.078 & 0.028 \\
\hline Experienced severe illness & 0.142 & 0.019 & 0.158 & 0.024 & 0.1 & 0.031 \\
\hline Experienced other severe risk & 0.336 & 0.026 & 0.333 & 0.030 & 0.344 & 0.050 \\
\hline Total number of households & 330 & & 240 & & 90 & \\
\hline
\end{tabular}

Source: Authors' calculation.

\section{b) Microinsurance Sector and Risk Exposure in Sri Lanka}

Sri Lanka has an infant microinsurance market in terms of penetration (1.48\%) and density (16.3 US $\$$ per inhabitant $)^{12}$, but a significant increase of microinsurance provision is suggested in the forthcoming years due to a high interest of private insurers in the low-income market, significant demand for risk management strategies of the low-income groups and strong efforts to provide microinsurance by potential intermediaries (Rajivan 2007, Roth et al. 2007). The origin of microinsurance schemes in Sri Lanka were funeral aid society concepts providing

11 The variable "risk assessment" is constructed from three questions related to the household's self perception of subjective exposure to health shocks, road or work accidents, and economic shocks compared with neighbouring households and one question about household's own rating of willingness to take risks using factor analysis.

12 Insurance penetration is defined as the total insurance premiums expressed as a percentage of the national GDP and thus, measures the level of risk awareness of population and significance of insurance in the economy. Insurance density indicates how much each inhabitant of a country spends each year for insurance services and so is a measure of the maturity of the industry in the economy. 
assistance in the case of death not only to members, but as well to their family members. In 1991 for instance All Lanka Mutual Assurance Organization ${ }^{13}$ (ALMAO), which is one of the apex microinsurance schemes in Sri Lanka, was started by seven cooperating Funeral Aid Societies (FASs). In our survey, we find that the five MFIs under examination serve a total of 241,800 clients with their microinsurance products. Nevertheless, there exists several microinsurance products including death benefits provided for instance by the five MFIs surveyed, which can be interpreted as a term life insurance, or providing in addition to death, accident, hospitalization, health and other benefits ${ }^{14}$.

The risk exposure of the households and especially the risks with the expected highest impact on household income and consumption are important to identify possibly insurable risks in Sri Lanka. We ask the households surveyed to list the most important, second most important and third most important sources of risk that they face in the forthcoming five years. The households report war and terrorism $(19 \%)$, which explicitly includes the fear of death or illness to the family due to a act of violence, as the most important peril they face in the future; a dramatic increase of input prices (18\%) and serious illness of working adult household member $(8 \%)$ are cited second and third most frequently. Other important family related shocks such as death or disablement of working adult or other household member are reported only from a minor proportion of the households. Nevertheless, it is evident that family related shocks are key risks faced by households in Sri Lanka, whereas a high share cites serious illness of a working adult household member as an important risk they face in the future. Yet, in Sri Lanka a death of any household member are marginally reported as an important peril for the household. However, in terms of severity the death or severe illness of any household member, accident or illness leading to permanent disability are in general seen as those risks that have the highest financial impact on the household income and consumption. Family related shocks are generally characterized by their low frequency and thus, they are possible and suitable to insure under a microinsurance scheme.

\section{c) Methodology}

We use econometric analysis to find the factors affecting insurance participation decision. The decision of buying insurance can be formulated in two interrelated choices. First, the choice of the household is related to the decision to buy or not buy any insurance. Second, if the household decides to buy insurance, then the second choice is to buy which type of insurance.

\footnotetext{
13 ALMAO is the main shareholder of Sanasa Insurance Company.

14 For instance, Yasiru Mutual Provident Society offers products with a coverage of death, accidents and health. Women's Development Federation in Hambantota provides special products in addition to death, hospitalization and health products: Marriage and child birth. ALMAO covers death, disability, hospitalization and life savings.
} 
Further, the household has to define for how many people in the household and for what extent of coverage the insurance is purchased. When estimating the determinants of insurance uptake based on cross-sectional data, one encounters the important challenge of dealing with both the problems of "endogeneity" and "self selection" (Jütting 2003). Therefore, we treat any implication on causal relationship with caution and intend to control as far as possible for potential endogeneity issues. Household heads who self-select the insurance uptake may have unobservable characteristics - related to preference or existing enrolment in a MFI - that makes it more likely for them to participate in an insurance scheme, which are mainly offered by such MFIs, and may influence their decision to use insurance (Waters 1999). That is why the two interrelated choices of insurance participation decision may proceed in three sequential steps.

To control for self-selection, we estimate two binary probit models to estimate the first two sequential steps of the insurance participation decision, i.e. the participation in an insurance scheme conditional on household's enrolment in any MFI. In the first probit model we estimate the determinants of household's enrolment in a MFI on the whole sample. In the second model, we investigate the determinants of household's usage of insurance on the sub-sample of the households that were members of a MFI, i.e. we examine insurance participation conditional on MFI membership. It is assumed that MFI enrolment or insurance participation of a household $(p)$ depend on the wealth status of the household $(w)$, characteristics of the household head $(H)$, who decides if the household joins or not, household characteristics $(Z)$, regional characteristics $(R)$ and on the error term $u$, who is uncovariant with the other regressors. The following equation is applied for both models using the described sample structure:

$$
p_{i}=f\left(w_{i}, H_{i}, Z_{i}, R, u\right)
$$

In order to estimate for each equation the probability of participation we use a binary probit model:

$$
\begin{aligned}
& p_{i}^{*}=\beta w_{i}+\alpha H_{i}+\phi Z_{i}+\delta R+u_{i} \\
& p_{i}^{*}=1 \text { if } p_{i}^{*}>0, \text { meaning the household } i \text { is member of a MFI (equation 1) or uses } \\
& \text { insurance (equation2), } \\
& p_{i}^{*}=0 \text { otherwise. }
\end{aligned}
$$

For the third step of the insurance participation decision, we apply a trivariate probit model on the use of different types of insurance, i.e. life, health and any other insurance. Since preliminary analyses of our three outcomes of interest revealed that there may be a correlation between the different outcome categories ${ }^{15}$ and use of any insurance is not exclusive among the

\footnotetext{
15 Analyses that ignore the correlations across outcomes, such as simple univariate probits, could therefore lead to biased results (Jones 2000). The coefficient estimates from the trivariate probit model account for unobserved correlation among the outcomes and are therefore less biased than those produced by three independent probit models.
} 
households, so that there are households who use more than one insurance type, we assume that household's choices for different types of insurance are interrelated. The trivariate probit model enables us to estimate three dichotomous dependent variables simultaneously and explicitly model the correlation in disturbance terms using a method of simulated maximum likelihood ${ }^{16}$. Therefore, we use it to estimate the determinants of the three different types of insurance, which is given by:

$$
\begin{array}{ll}
L^{*}=X^{\prime} \beta_{L}+\varepsilon_{L} & L^{*}=1 \text { if } L^{*}>0,0 \text { otherwise, } \\
H^{*}=X^{\prime} \beta_{H}+\varepsilon_{H} & H^{*}=1 \text { if } H^{*}>0,0 \text { otherwise, } \\
O^{*}=X^{\prime} \beta_{O}+\varepsilon_{O} & O^{*}=1 \text { if } O^{*}>0,0 \text { otherwise, }
\end{array}
$$

where $L^{*}, H^{*}$ and $O^{*}$ are the true, unobserved propensities to use life insurance, health insurance or any other insurance. The term $\mathrm{X}^{\prime}$ represents the vector of independent variables, i.e. the sociodemographic control variables. We assume that the distribution of the three outcomes is multivariate normal, i.e.:

$$
E\left[\varepsilon_{L}\right]=E\left[\varepsilon_{H}\right]=E\left[\varepsilon_{O}\right]=0 \quad \text { and } \quad \operatorname{Var}\left[\varepsilon_{L}\right]=\operatorname{Var}\left[\varepsilon_{H}\right]=\operatorname{Var}\left[\varepsilon_{O}\right]=1
$$

In multivariate probit models the computation of marginal effects are difficult. We therefore calculated the average partial effects (APEs) on the marginal probabilities of the independent variables for each equation by averaging sample partial effects ${ }^{17}$.

\section{Estimating the Patterns of Microinsurance Participation}

\section{a) Marginal Coefficients for Microfinance Enrolment and Insurance Participation}

We calculate two equations to estimate the first two sequential steps of the insurance participation decision. Using a conditional probit model, the estimates are presented in Table 2. The first equation is estimated on the whole sample and has a dependent variable equal to 1 if the household is a member of a MFI (and respectively uses any financial service) and 0 otherwise. The second equation uses a dependent variable equal to 1 if the household participates in an insurance scheme estimated on the sub sample of the households that were members of a MFI, i.e. we examine insurance participation conditional on MFI membership. As our primary variable of interest is membership in a MFI, we hypothesize that, after controlling for individual, household and regional characteristics, members of a MFI have better access to and are more likely to use any type of insurance than non-members. Two models specifications have been

\footnotetext{
16 We use the Stata application mpprobit that uses the Geweke-Hajivassiliou-Keane simulator (Cappellari and Jenkins 2003, Greene 2003, Kis-Katos 2007).

17 We use the Stata application muppred to calculate the predicted probabilities of a positive response for each of the three outcomes (Capellari and Jenkins 2003) and based on this, we calculate the APEs using the Stata routine margeff(Bartus 2005).
} 
estimated for each dependent variable and estimation ${ }^{18}$. Further, we calculated marginal effects for two reference households ${ }^{19}$.

Table 2: Institution Membership and Participation Conditional on Membership Sri Lanka

\begin{tabular}{|c|c|c|c|c|}
\hline \multirow[t]{2}{*}{ Variable } & \multirow{2}{*}{$\begin{array}{c}\text { Membership } \\
\text { (I) }\end{array}$} & $\begin{array}{l}\text { Bought Conditional on } \\
\text { Membership }\end{array}$ & \multirow{2}{*}{$\begin{array}{c}\text { Membership } \\
\text { (II) }\end{array}$} & $\begin{array}{l}\text { Bought Conditional on } \\
\text { Membership }\end{array}$ \\
\hline & & (I) & & (II) \\
\hline Female head & $0.3278^{* * *}$ & -0.0021 & $0.2503^{* * *}$ & -0.0069 \\
\hline Household size & $-0.0583^{* *}$ & $0.0069^{* * *}$ & $-0.0936^{* * *}$ & $0.0055^{* *}$ \\
\hline Age & -0.0482 & $-0.0036^{* *}$ & -0.0084 & $-0.0029 * *$ \\
\hline Age squared & 0.0003 & $0.00003^{*}$ & -0.00007 & $0.00003^{* *}$ \\
\hline \multicolumn{5}{|l|}{$\begin{array}{l}\text { Education of household head } \\
\text { (base: tertiary education) }\end{array}$} \\
\hline No or primary education & $-0.9615^{* * *}$ & $0.6278^{* * *}$ & -0.9692 & 0.2097 \\
\hline Secondary Education & 0.0532 & 0.0118 & -0.0172 & 0.0075 \\
\hline \multicolumn{5}{|l|}{$\begin{array}{l}\text { Occupation of household head } \\
\text { (base: formal employee/employer) }\end{array}$} \\
\hline Head is selfemployed & $-0.8374 * * *$ & 0.0125 & $-0.8161 * * *$ & 0.0098 \\
\hline Head is unemployed & $-0.7462^{* * *}$ & 0.0096 & $-0.7659 *$ & 0.0039 \\
\hline Asset Index & $0.2132^{* * *}$ & $0.0171^{* * *}$ & - & - \\
\hline \multicolumn{5}{|l|}{$\begin{array}{l}\text { Asset Quintiles (base: richest } \\
20 \% \text { ) }\end{array}$} \\
\hline Quintile 1 & - & - & $-0.9996^{* * *}$ & $-0.2621 * * *$ \\
\hline Quintile 2 & - & - & $-0.9999 * * *$ & $-0.0251 * * *$ \\
\hline Quintile 3 & - & - & $-0.9984 * * *$ & $-0.0781 * * *$ \\
\hline Quintile 4 & - & - & - & 0.0033 \\
\hline Land Ownership & 0.2632 & -0.0017 & $0.3424 *$ & $0.0046^{* *}$ \\
\hline Remittance & $0.0899 *$ & 0.5448 & $0.0901 * *$ & $0.6719 * *$ \\
\hline Self risk assessment & 0.0028 & $0.0031 * *$ & 0.0408 & 0.0017 \\
\hline \multicolumn{5}{|l|}{$\begin{array}{l}\text { Household's risk experience (base: } \\
\text { no risk experience) }\end{array}$} \\
\hline Experienced death & - & 0.1648 & - & 0.0361 \\
\hline Experienced severe illness & -0.1737 & -0.0029 & -0.1308 & $-0.0043^{* *}$ \\
\hline Experienced other severe risk & $0.4426 * * *$ & $-0.0422 *$ & $0.4806^{* * *}$ & $-0.0419 *$ \\
\hline Regional Dummies & Yes & Yes & Yes & Yes \\
\hline Observations & 330 & 304 & 330 & 304 \\
\hline
\end{tabular}

Source: Authors' calculation.

Note: Probit model. Coefficients normalized to display marginal effects. The asterisks indicate level of significance (Robust $\mathrm{z}$ statistics): ${ }^{* * *}$ significant at 1 percent, ${ }^{* *}$ significant at 5 percent, ${ }^{*}$ significant at 10 percent.

\footnotetext{
18 The first one includes among the other regressors an asset endowment index as continuous variables and the second uses dummies for asset endowment quintiles.

19 (1) we identify a female headed household who has 8 household members, a household head at age 45 years with no formal or only primary education, but self-employed, with an asset endowment index of zero, without any land, who receives remittances, has an risk assessment index of one, has experienced a death and illness of a household member and as well any other shock in past five years, (2) a male headed household who has 4 household members, secondary education, an asset endowment index of two, without any remittances and as well for the other variables the same outcomes as the first reference household. Important to note is that it may be better to create a benchmark value - an reference case - for which the marginal effects are calculated (Cameron and Trivedi 2009).
} 
The results provide evidence that female-headed households are significantly more likely to be member in a MFI than male-headed households in Sri Lanka. In general, female-headed households can be assumed as less wealthy than their male-headed counterparts in developing countries, so they have significantly lower financial resources to access or participate in the microfinance market. For Sri Lanka we find the opposite. In Sri Lanka, women are assigned as a particular target group of MFIs due to higher repayment probabilities, the approach of group loans to socially connected women and a higher incentive to provide security to their families. Therefore, we find here that women-led households are more likely to participate in a microfinance scheme than their male-headed counterparts. Household size is significantly negatively linked with the membership in a MFI. In the data set household size is highly correlated with the number of dependents ${ }^{20}$. The probability decreases for the first reference household by -0.08 and for the second one by -0.02 . This implies that on the one hand, households with a larger number of dependents have a higher share of consumption due to their income, are less able to provide collateral and thus, have limited access to microfinance institutions. However, on the other hand, they may be more exposed to risks such as death or illness due to the higher number of dependents and so have a higher incentive to use their limited resources to obtain risk-reducing effects.

In line with our expectations and previous findings, we find that household heads with no formal, primary or secondary education are less likely to be enrolled in a MFI or participate in the microfinance market than higher educated heads ${ }^{21}$. A higher level of education may raise household's ability to understand the benefits of risk management, in particular of microfinancial services and so household's willingness to be member in a MFI. From a supply side, high educated household heads have generally better income earning opportunities and thus, they have better access to the microfinancial markets than lower educated heads. In accordance with this, we confirm earlier contributions that households with a head who is either self-employed or contractual worker are significantly less likely to obtain membership in a MFI than households with a head who is either regularly employed or an employer. Due to irregular and especially low incomes, such households have only limited access to the microfinance market. The evidence on the association between household economic status and MFI membership indicates that better off households are more likely to become a member of a respective MFI. For the asset index the probability for the female headed reference household increase by 0.297 , while for the male headed reference household by 0.553 . Households from the richest quintile are more likely to be enrolled in a MFI compared to those from the poorest quintiles (Table 2), so the poorest

20 The correlation coefficient for Sri Lanka is 0.79 .

${ }^{21}$ It may be better to use here years of schooling instead of the three educational dummies, but the survey do not include reliable data on that. 
households are not covered by the MFIs under study in Sri Lanka. This may indicate that the poor have a lower accessibility to enter a MFI and to use respective financial services than their better off counterparts (Hulme and Mosley 1997, Navajas et al. 2002, Datta 2004). The exclusion from the market can appear voluntarily and involuntarily, whereas it is rather unlikely that the poor choose by themselves not to enter the microfinance market. Households who receive any remittances are more likely to be a member in a MFI and so are more likely to use micro financial services in Sri Lanka. This implies that remittances functions here as additional financial resources for the use of financial services.

Conditional on MFI membership, the estimates for insurance participation are presented in Table $2^{22}$. Among the households who are member in any MFI, household size is significantly positively associated in Sri Lanka. This implies that among MFI members in Sri Lanka, larger households are more likely to participate in insurances, as they may have high incentives to uptake insurance as an ex ante risk management strategy, for instance due to a high exposure to family related risks. Further, they may be not faced with a lower access to insurance markets due to a higher number of dependents and its influence on their socioeconomic situation. We find that age of the household head is significantly related to insurance participation. The turning point is $57^{23}$ years of age, which implies that household heads with increasing age do not request more insurance. One explanation for this outcome may be that as well older household heads with MFI membership are less educated and thus, less able to understand insurance products and markets than their younger counterparts.

In contrast to our expectations and previous findings, we find that in Sri Lanka no formal, primary or secondary education is positively correlated with insurance uptake, whereas only one estimate is statistically significant. Lower educated households have a lower understanding of insurance products than higher educated households do, which is a often identified constraint in selling insurance to the poor in developing countries (McCord 2001). Further, lower educated households belong typically to the weakest socioeconomic groups. Recent contributions in the literature show that it might be better to control for factors related to financial literacy in addition to common educational variables (Giné et al. 2008, Cole et al. 2009). We confirm our expectations that households with an higher asset endowment are more likely to use insurance. Households from the richest quintile are more likely to use insurance compared to those from the poorest quintiles (Table 2). Being an indication of household's socioeconomic status, this results display that better-off households are less likely to be excluded from insurance

\footnotetext{
22 We have estimated binary probit models for insurance use without control for the membership in any MFI. We find changes due to the signs and significance levels of the estimation coefficients.

${ }^{23}$ The turning point is 49 years of age for the specification II.
} 
markets. Remarkably, microinsurance is so far not able to reach the poorest households in Sri Lanka.

Remittances are highly associated with the use of insurance. In contradiction to earlier findings from Bendig et al. (2009) for Ghana, we find a positive association of remittances with insurance uptake for Sri Lanka. Here, remittances may function more as additional financial resource to uptake insurance. In contrast to earlier findings in the literature (Giné et al. 2008, Bendig et al. 2009), we find that households who perceived themselves more exposed to risk among the MFI members, are significantly more likely to use insurance in Sri Lanka ${ }^{24}$. This indicates that households may not see insurance as an additional risk due to mistrust in the provider or misunderstanding of the offered products. By development economists, the poor are the most risk averse households (Ray 1999). As the insured are the better off households, this may indicate for Sri Lanka that the self perception of risk exposure of the insured households is higher due to a lower asset endowment compared to the non-insured households, or thus, the poorer households are not excluded from the insurance markets in spite of their higher risk exposure, if they are members in a MFI. For the three risk dummies, we find that households who experienced any other shock are significantly less likely to use insurance.

\section{b) Determinants of Different Types of Insurance Participation}

For the third sequential step of household's insurance participation decision, we employed multivariate probit models to investigate what determines the usage of different types of insurance, i.e. life, health and other insurances, offered by microfinance institutions in Sri Lanka. The results of the trivariate probit regressions, showing the APEs of the explanatory variables on the marginal probability to use any type of insurance, are presented in

Table 3 and in Table 5 (in Appendix) ${ }^{25}$. Different to the previous estimations, two more explanatory variables - namely married head and the ratio of ill household members - are added here according to the relevance of bequest motives and adverse selection.

It is important to note that the three outcome categories, i.e. the types of insurance, are not mutually exclusive. The estimated correlation coefficients, listed at the bottom of the tables,

\footnotetext{
${ }^{24}$ However, households' self perception of risk exposure can only function as a proxy for the risk aversion of the household. It may gives an indication that a higher exposure to risk of a household may represent a higher awareness of the household towards risks and its higher aversion towards risks. Due to the perceptive measurement of the households' self perception of risk exposure, it can function only as an approximate measure of the individual's risk aversion and thus, is linked to limited explanatory power.

${ }^{25}$ Similar to the previous estimations, we estimate two specifications, one with an asset endowment index and one with dummies for asset endowment quintiles.
} 
indicate that the residuals of the three outcome categories are correlated ${ }^{26}$. Two of the estimated correlation coefficients for Sri Lanka are negative and statistically significant, suggesting that there are common unobservable factors that influence an individual's decision to purchase different types of insurance ${ }^{27}$. The correlation coefficient between the unexplained part of the use of life and other insurance amounts to -0.69 and between health and other insurance to -0.41 suggesting that there are unobservable factors that influence household's decision to purchase life or any other insurance and respectively health or any other insurance ${ }^{28}$. This outcome states that from households perspective the participation in life or any other insurance and health or any other insurance are conflicting alternatives.

Female-headship of a household is positively associated with the use of micro health insurance in Sri Lanka, which may deflect a higher incentive to provide security, especially health care, to the household compared to male-headed households. Female headed households are generally less wealthy and thus more exposed to risks than households with a male breadwinner. Women are the main health caregivers in the family due to traditional role models of women, so they prioritize health-related expenditures for their family than men including the premium paid to a micro health insurance scheme (Chankova et al. 2008). Household size is significantly positively associated with the participation in micro life and any other insurance. The access to life or any other insurance may as well not be limited for larger households due to a higher number of dependents. In our first specification household size, indicating the number of dependents in the household is a economically and statistically significant predictor of micro life insurance participation due to an intended bequest motive (Hurd 1987, Hurd 1994). However, there is no significant relationship between the micro life insurance participation and the marriage status of the head, which is another possible determinant according to bequest motives. If the household head is married, is significantly positively linked to the uptake of micro health insurance in our first specification and negatively related to the use of any other insurance in our second specification. Married household heads - similar to female-headed households - seem to have a higher propensity to internalize the costs and consequences related to health care than unmarried heads. In contrast to earlier findings in the literature, we find no evidence on the existence of adverse selection and ex post moral hazard, as there is no significant outcome for the ratio of ill household members ${ }^{29}$. We find no life-cycle effect for any of the three insurance types, which indicates an u-shaped age pattern for Sri Lanka. There is significant evidence for such age

\footnotetext{
${ }^{26}$ I.e. separate probit estimations for each outcome yields very similar coefficients to those of the multivariate probit model. ${ }^{27}$ Hence, the application of the trivariate probit regression is appropriate for the Sri Lankan case, as the correlations between the error terms of two equations are all zero can be rejected at a high significance level. However, we have estimated binary probit models for each of the insurance types separately. We find only slight changes due to the signs and significance levels of the estimation coefficients.

${ }^{28}$ In the second specification, these correlation coefficients amount to -0.71 and -0.58 .

${ }^{29}$ We checked as well for the explanatory variable households with a sick household head and find no significant association.
} 
pattern for micro life in both specifications and for micro health insurance participation in the second specification. Household heads have a decreasing willingness to pay up to a specific age, before the willingness to pay for insurance increases due to higher incentives to protect their families from certain hazards.

Table 3: Multivariate Probit Results on the Type of Insurance for Sri Lanka (I)

\begin{tabular}{|c|c|c|c|c|c|c|c|c|c|}
\hline \multirow[t]{2}{*}{ Variable } & \multicolumn{3}{|c|}{ Life Insurance } & \multicolumn{3}{|c|}{ Health Insurance } & \multicolumn{3}{|c|}{ Other Insurance } \\
\hline & Coefficient & APEs & z-statistic & Coefficient & APEs & z-statistic & Coefficient & APEs & z-statistic \\
\hline Female head & 0.016 & 0.0003 & 0.00 & 1.318 & 0.0005 & $1.94^{* *}$ & -0.063 & -0.004 & -0.11 \\
\hline Household size & 0.241 & 0.049 & $2.39 * *$ & 0.234 & 0.00001 & 1.24 & 0.336 & 0.028 & $3.33 * * *$ \\
\hline Married head & 0.056 & 0.009 & 0.09 & 1.322 & 0.00001 & $3.12 * * *$ & -0.906 & -0.104 & -1.59 \\
\hline $\begin{array}{l}\text { Ratio of ill } \\
\text { household members }\end{array}$ & 0.335 & 0.073 & 0.38 & -0.146 & $-2.99 \mathrm{e}-06$ & -0.15 & 0.077 & 0.005 & 0.23 \\
\hline Age & -0.204 & -0.032 & $-3.91 * * *$ & -0.109 & $-2.41 e-06$ & -0.87 & -0.118 & -0.006 & $-1.74^{*}$ \\
\hline Age squared & 0.002 & 0.0003 & $4.24 * * *$ & 0.001 & $2.88 \mathrm{e}-08$ & 0.90 & 0.0008 & 0.00005 & 1.12 \\
\hline $\begin{array}{l}\text { Education of } \\
\text { household head } \\
\text { (base: tertiary } \\
\text { education) }\end{array}$ & & & & & & & & & \\
\hline $\begin{array}{l}\text { No or primary } \\
\text { education }\end{array}$ & 1.939 & 0.568 & $5.02^{* * *}$ & 3.094 & 0.031 & $2.76^{* * *}$ & 0.079 & 0.005 & 0.12 \\
\hline Secondary Education & 0.958 & 0.193 & $5.09 * * *$ & 1.829 & 0.0005 & $2.06^{* *}$ & 0.197 & 0.013 & 0.54 \\
\hline $\begin{array}{l}\text { Occupation of } \\
\text { household head } \\
\text { (base: formal } \\
\text { employee/employer) }\end{array}$ & & & & & & & & & \\
\hline Head is selfemployed & 0.768 & 0.127 & $1.69 *$ & -0.811 & -0.00005 & $-1.70^{*}$ & -0.358 & -0.024 & -1.35 \\
\hline Head is unemployed & 0.332 & 0.066 & 0.82 & -0.905 & -0.00001 & $-2.37 * *$ & -0.439 & -0.022 & $-2.01 * *$ \\
\hline Asset Index & 1.117 & 0.338 & $6.29 * * *$ & 1.460 & 0.002 & $3.30^{* * *}$ & 0.503 & 0.049 & $2.71 * * *$ \\
\hline Land Ownership & 0.528 & 0.079 & 1.35 & -0.335 & -0.00001 & -0.42 & 0.062 & 0.004 & 0.25 \\
\hline Remittance & 0.629 & 0.154 & 1.35 & -1.467 & $-8.54 \mathrm{e}-06$ & -1.38 & 1.433 & 0.259 & 1.33 \\
\hline $\begin{array}{l}\text { Self risk assessment } \\
\text { Household's risk } \\
\text { experience (base: no } \\
\text { risk experience) }\end{array}$ & 0.016 & 0.003 & 0.08 & 0.194 & $8.40 \mathrm{e}-06$ & 1.18 & -0.048 & -0.003 & -0.26 \\
\hline Experienced death & 0.709 & 0.177 & 1.15 & 1.000 & 0.0003 & $3.45^{* * *}$ & 0.564 & 0.055 & 1.52 \\
\hline $\begin{array}{l}\text { Experienced severe } \\
\text { illness }\end{array}$ & -0.051 & -0.009 & -0.11 & 1.199 & 0.0004 & 1.35 & -1.206 & -0.037 & $-1.69 *$ \\
\hline
\end{tabular}




\begin{tabular}{|c|c|c|c|c|c|c|c|c|}
\hline $\begin{array}{l}\text { Experienced other } \\
\text { severe risk }\end{array}$ & -0.956 & -0.143 & $-3.18^{* * *}$ & $2.97 \mathrm{e}-06$ & 0.25 & -1.185 & -0.059 & $-3.45^{* * *}$ \\
\hline Regional dummies & Yes & - & - & Yes & - & Yes & - & - \\
\hline $\begin{array}{l}\text { Est. correlation } \\
\text { coeff. }\end{array}$ & $\varrho_{21}=0.094$ & & 1.04 & $\varrho_{31}=-0.693$ & $-9.13 * * *$ & $\varrho_{32}=-0.411$ & & $-3.03 * * *$ \\
\hline
\end{tabular}

Source: Authors' calculation.

Note: Results of the trivariate probit model are estimated by SML with 20 pseudorandom draws. t-statistics refer to the estimated coefficients and are based on robust standard errors. Average partial effects (APEs) are calculated with respect to the marginal probability of each type of insurance. The model also includes a constant. Sample size is $\mathrm{N}=330$ observations. The asterisks indicate level of significance: *** significant at 1 percent, ** significant at 5 percent, * significant at 10 percent.

In contrast with our expectations, household heads with no formal, primary or secondary education are significantly more likely to buy life and health insurance in Sri Lanka. However, this implies that lower educated household heads do not have a higher limited access to insurance or a lower willingness to pay for microinsurance than high educated heads. Nevertheless, they may have lower income earning opportunities and therefore a higher incentive to secure their families from the negative outcomes of certain shocks, such as death or sickness. Household heads with a lower educational attainment have a higher propensity to participate in any types of the microinsurance schemes. Due to previous contributions in the literature, it would be better to use additional determinants related to financial literacy to capture the relationship between limited financial literacy of the low-income households and their propensity to participate in different types of microinsurance schemes (Giné et al. 2008, Cole et al. 2009). We find similar outcomes for the household heads who are either self-employed or unemployed in Sri Lanka. Selfemployment and unemployment are significantly negatively associated with the use of micro health insurance and unemployment only to the uptake of any other insurance. Both occupation status are related to lower income earning possibilities and so reduce household's willingness and abilities to pay for any micro health or any other insurance. In contrast to this, we find that selfemployment is positively related to the micro life insurance participation, but is only significant in the first specification. Being an indication of household's socioeconomic status, households with an higher asset endowment are more likely to use life, health or any other insurance in Sri Lanka. Households from the poorest quintile are significantly less likely to participate in a micro life and health insurance scheme compared to those from the richest quintile (Table 5 in Appendix). So far, the poorest households have still limited access to the insurance market and especially to socalled micro life and micro health insurance policies. Interestingly, land ownership confirms this fact, as it is positively linked to the uptake of life and other insurance in the second specification (Table 5 in Appendix).

Households, who perceived themselves more exposed to risk, are significantly more likely to participate in a micro health insurance scheme in the second specification (Table 5 in Appendix). For the three risk dummies, we find that the experience of a death of a household 
member is significantly positively related with the participation in a micro health insurance scheme in the first specification and with the uptake of any other insurance in the second specification. The experience of a severe illness is significantly negatively related to the use of any other insurance. If a household experienced any severe other risk in the past five years, the household is significantly less likely to participate in a micro life and any other insurance. Households who experienced a family related shock - namely a death of a household member have a higher incentive to secure for the negative outcome of such shock in the future, whereas after the experience of illness of a household member and any other severe shock the households may not see insurance as an appropriate risk management strategy, as they do not have the financial resources for the purchase or their access is restricted.

\section{Conclusion}

We estimate three sequential steps of household's insurance participation decision and present hereby evidence on the determinants of insurance participation conditional on household's MFI enrolment and factors affecting household's decision to participate in which type of microinsurance. The residuals of two of the estimated correlation coefficients for Sri Lanka are significantly negatively correlated. There is evidence that the participation in life or any other insurance and health or any other insurance are conflicting alternatives for the households. Additionally, our results for our study site reveal several patterns.

First, female-headship of a household is positively associated with the enrolment in a MFI and the use of micro health insurance in Sri Lanka. Microinsurance providers, especially in the case of micro health insurance, should take into consideration the higher propensity of femaleheaded households to participate in such schemes. Second, household size is negatively linked with the membership in a MFI. In contradiction to this, we find that household size is positively associated with general insurance participation and the usage of micro life insurance presumably due to an intended bequest motive - and any other insurance in Sri Lanka. Third, there exists no life-cycle effect at all, but an u-shaped age pattern may be confirmed. Fourth, we find that better off households are more likely to become a member of a respective MFI, while the poor have a lower accessibility to enter any MFI under study. Conditional on household's enrolment in a MFI, the poor are more likely to be excluded from the insurance market. In detail, the poor are less likely to participate in a micro life and micro health insurance scheme. It is important to note that the microinsurance products we study have not yet succeeded in proportionately reaching the most vulnerable households that presumably would benefit most from protection against hazards such as death, illness or any other insurable peril. Extending the financial accessibility through MFIs and better suitability to the specific target group may 
therefore be two strong pillars of a strategy for improving access to insurance products for the low-income population groups. From household perspective, it is crucial to obtain efficient risk management measures for asset building, wealth creation and hence social protection. As microinsurance is as well motivated by the lack of any social security measures, especially social health insurance systems, it is essential to provide affordable public social security measures to prevent the poor from the consequences related to family associated shocks, if the poor are considered to poor to participate in microinsurance schemes.

Fifth, there is evidence that education of the household head is a strong determinant of household's MFI enrolment and insurance participation in Sri Lanka. This indicates that information on MFI enrolment and especially on the use and type of insurances has to be disseminated by the MFIs in a way that caters to those who have little or no education to ensure that these population groups are not excluded from insurance markets. Further, the implementation and promotion of financial education measures by the providing MFIs may improve the understanding and knowledge about insurance, reduce mistrust in the providing institutions among possible target groups and existing clients in the communities and lead in the long run to financial capable individuals and households as well in the rural communities. Sixth, we confirm that remittances may function as an additional financial resource for household's MFI membership and especially for insurance participation.

Beyond, there is evidence that the experience of a death or illness of a household member, or any other shock in the past five years is related to household's MFI enrolment and the use of insurance. The experience of a death is positively linked to the participation in a micro health insurance scheme, while the experience of illness is negatively linked to the uptake of any other insurance in Sri Lanka. In the beginning, we state that family related shocks are key risks faced by households in the future, which are mainly characterised by idiosyncratic, low loss and single-event types of risk. Interestingly, there is evidence in our estimates that the household's experience of a family related shock is positively related to the use of any of the existing microinsurance programs under study. This implies that existing programs may function as effective ex ante risk management strategies protecting households from the potentially catastrophic expenditures associated with family related shocks. Though, there is still a strong need to extend their geographical coverage and the accessibility to the poor and adapt the product features more to the needs of their target groups, i.e. the most vulnerable population groups in the regions under study, using the experiences from the informal financial markets and existing products there. 


\section{References}

Armendáriz, Beatriz and Jonathan Morduch (2005): The Economics of Microfinance, Chapter 6 Savings and Insurance, Cambridge, Mass. and London: The MIT Press.

Arun and Bendig (2010a): Risk Management among the Poor: The Case of Microfinancial Services, IZA Discussion Paper, No. 5174, September 2010, Bonn: Institute for the Study of Labor.

Arun and Bendig (2010b): Participation in Micro Life Insurance in Sri Lanka: The Role of Bequest Motives, forthcoming.

Asfaw, A. (2003): Cost of Illness, demand for medical care, and the prospect of community bealth insurance schemes in the rural areas of Ethiopia, Frankfurt: Peter Lang Eds.

Barsky, R.B., Juster F. Th., Kimball M.S. and Spapiro M.D. (1997): Preference parameters and behavioral heterogeneity: an experimental approach in the health and retirement study, in: Quarterly Journal of Economics, 112: 537-579.

Bartus, Tamás (2005): Estimation of marginal effects using margeff, in: The Stata Journal, 5(3): 309-329.

Beck, Thorsten and Webb, Jan (2002): Economic, Demographic, and Institutional Determinants of Life Insurance Consumption Across Countries, The World Bank Economic Review, 17: 51-88.

Bendig, Mirko, Giesbert, Lena and Steiner, Susan (2009): Savings, Credit and Insurance: Household Demand for Formal Financial Services in Rural Ghana, GIGA Working Paper Series, No. 94, January 2009, Hamburg: German Institute of Global and Area Studies.

Bhat, Ramesh and Nishant Jain (2006): Factoring Affecting the Demand for Health Insurance in a Micro Insurance Scheme, Working Paper No. 2006-07-02, Ahmedabad: Indian Institute of Management.

Browne, Mark J. and Kim, Kihong (1993): An International Analysis of Life Insurance Demand, Journal of Risk and Insurance, 60: 616-634.

Browne, Mark J. and Helen I. Doerpinghaus (1993): Information Asymmetries and Adverse Selection in the Market for Individual Medical Expense Insurance, The Journal of Risk and Insurance, 60: 300-312.

Cameron, Colin A. and Pravin K. Trivedi (2009): Microeconometrics Using Stata, First Edition, College Station: Stata Press.

Capellari, Lorenzo and Stephen P. Jenkins (2003): Multivariate probit regression using simulated maximum likelihood, in: The Stata Journal, 3(3): 278-294.

Cawley and Phillipson, 1999: An Empirical Examination of Information Barriers to Trade in Insurance, American Economic Review, 89(4): 827-846.

Chankova, Slavea, Sulzbach, Sara and Diop, Francois (2008): Impact of mutual health organizations: evidence from West Africa, Health Policy and Planning, 23(4): 264-276. 
Cohen, Monique, Michael McCord and Jennefer Sebstad (2005): Reducing Vulnerability: Demand for and Supply of Micro Insurance in East Africa, in: Journal of International Development 17(3): 319-325.

Cole, Shawn, Giné, Xavier, Tobacman, Jeremy, Topalova, Petia, Townsend, Robert M. and James Vickery (2009): Barriers to Household Risk Management: Evidence from India, Havard Business School Finance Working Paper 09/116, Boston: Harvard Business School.

Churchill, Craig (ed.) (2006): Protecting the Poor. A Micro Insurance Compendium, Genf: ILO.

Datta, Dipankar (2004): Microcredit in rural Bangladesh. Is it reaching the poorest?, in: Journal of Microfinance, 6(1): 55-81.

Dercon, Stefan (2002): Income Risk, Coping Strategies, and Safety Nets, in: World Bank Research Observer, 17(2): 141-166.

Dror, D.M., Radermacher, R. and Koren, R. (2007): Willingness to Pay for Health Insurance Among Rural and Poor Persons: Field Evidence from Seven Micro Health Insurance Units in India, Health Policy, Vol. 82, No. 1.

Enarsson, Sven and Wirén, Kjell (2006): ALMAO and YASIRU Sri Lanka, CGAP Working Group on Microinsurance - Good and Bad Practices - Case Study No 21.

Fafchamps, Marcel, and Susan Lund (2003): Risk-sharing networks in rural Philipines, Journal of Development Economics 71 (2): 261-287 .

Giné, Xavier, Robert Townsend und James Vickery (2008): Patterns of rainfall insurance participation in rural India, in: The World Bank Economic Review, 22(3): 539-566.

Giné, Xavier and Dean Yang (2009): Insurance, Credit and Technology Adoption: Field Experimental Evidence from Malawi, Journal of Development Economics 89 (1), pp. 1-11.

Greene, William H. (2003): Economic analysis, Third edition, Upper Saddle River: Prentice Hall.

Hamid, Syed Abdul, Roberts, Jennifer and Paul Mosley (2010): Can Micro Health Insurance Reduce Poverty? Evidence from Bangladesh, Sheffield Economic Research Paper Series, No. 2010001, Sheffield: University of Sheffield.

Holzmann, R. and Joergensen, S. (2000): Social Risk Management: A New Conceptual Framework for Social Protection, and Beyond, Social Protection Discussion Paper No. 0006, World Bank: Washington DC.

Hulme, David and Paul Mosley (1997): Finance for the poor of the poorest? Financial innovations, poverty and vulnerability, in: Geoffrey Wood and Iffath Sharif (eds.): Who needs credit? Poverty and finance in Bangladesh, Dhaka: University Press: 96-129.

Hurd, Michael D. (1987): Savings of the Elderly and Desired Bequests, in: American Economic Review, 77, pp. 298-312.

Hurd, Michael D. (1994): Measuring the Bequest Motive: The Effect on Children on Saving by the Elderly in the United States, in: Toshiaki Tachibanaki (eds.): Savings and Bequests, Michigan: The University of Michigan Press, pp. 111-136.

Inkmann, Joachim and Alexander Michaelides (2010): Can the Life Insurance Market Provide Evidence for a Bequest Motive?, Working Paper, Central Bank of Cyprus, London School of Economics, 2010. 
Ito, Seiro and Hisaki Kono (2010): Why is the Take-up of Microinsurance so Low? Evidence from a Health Insurance Scheme in India, The Developing Economies 48 (1), pp. 74-101.

Jones, Andrew (2007): Applied econometrics for health economists: A practical guide, Second Edition, Oxford: Radcliffe Publishing Ltd.

Jütting, Johannes (2003): Do Community-based Health Insurance Schemes Improve Poor People's Access to Health Care? Evidence From Rural Senegal, in: World Development, 32(2): 273-288.

Kazianga, Harounan and Christopher Udry (2006): Consumption smoothing? Livestock, insurance and drought in rural Burkina Faso, Journal of Development Economics 79 (3): 413-446.

Kis-Katos, Krisztina (2007): The work-schooling trade-off of Indian children, mimeo.

Lewis, Frank (1989): Dependents and the Demand for Life Insurance, American Economic Review, 79: 452-466.

Kurosaki, Takashi and Marcel Fafchamps (2002): Insurance market efficiency and crop choices in Pakistan, Journal of Development Economics 67 (3): 419-453.

Loewe, Markus et al. (2001): Improving the Social Protection of the Urban Poor and Near-Poor in Jordan, Reports and Working Paper 12, Bonn: Deutsches Institut für Entwicklungspolitik.

McCord; Michael J. (2001): Health care microinsurance - case studies from Uganda, Tanzania, India and Cambodia, Small Enterprise Development, 12(1): 25-38.

McCord, Michael J., Gaby Ramm and Elizabeth McGuinness (2006): Microinsurance. Demand and Market Prospects, Study Commissioned by Allianz, GTZ, UNDP.

Morduch, Jonathan (1995): Income Smoothing and Consumption Smoothing, in: Journal of Economic Perspectives, 9(3): 103-114.

Morduch, Jonathan (1999): Between the State and the Market: Can Informal Insurance Patch the Safety Net?, in: World Bank Research Observer, 14(2): 187-207.

Navajas, Sergio et al. (2000) : Microcredit and the poorest of the poor. Theory and evidence from Bolivia, in: World Development, 28(2): 333-346.

Outreville, Francois J. (1996): Life Insurance Markets in Developing Countries, Journal of Risk and Insurance, $63: 263-278$.

Pauly, M.V. (2004): The demand for health insurance: insights from theory and voluntary markets in less-developed countries, Background paper presented at Wharton Impact Conference on Voluntary Health Insurance in Developing Countries, March 15-16, University of Pennsylvania, http://hc.wharton.upenn.edu/impactconference/index.html (accessed on 07.11.2008).

Rajivan, Anuradha (2007): Proceedings of the Regional Workshop on Microinsurance Sector Development, June 2007: Building Security for the Poor - Potential and Prospects for Microinsurance in India, Colombo.

Ray, Debraj (1999): Development Economics, Princeton: University Press.

Roth, Jim, McCord, Michael and Liber, Dominic (2007): The Landscape of Microinsurance in the World's 100 Poorest Countrie, The Microinsurance Centre: LLC. 
Rothschild, Michael and Joseph E. Stiglitz, 1976: Equilibrium in Competitive Insurance Markets: An Essay on the Economics of Imperfect Information, Quarterly Journal of Economics, 90: 63049.

Siegel, Paul B., Alwang, Jeffrey and Sudharshan Canagarajah (2001): Viewing Microinsurance as a Social Risk Management Instrument, Social Protection Discussion Paper No. 0116, World Bank: Washington DC.

Townsend, Robert (1995): Consumption Insurance: An Evaluation of Risk-Bearing Systems in Low-Income Economies, in: Journal of Economic Perspectives, 9(3): 83-102.

Truett, Dale B. and Truett, Lila J. (1990): The Demand for Life Insurance in Mexico and the United States: A Comparative Study, Journal of Risk and Insurance, 57: 321-328.

Waters, H. (1999): Measuring the impact of health insurance with a correction for selection bias a case study of Ecuador. Health Economics and Econometrics, 8: 473-483.

Worldbank (2008): Finance for All? Policies and Pitfalls in Expanding Access, World Bank Policy Research Report, Washington DC: World Bank.

Zeller, Manfred and Manohar Sharma (2002): Access to and demand for financial services by the rural poor: A multicountry synthesis, in: Manfred Zeller and Richard L. Meyer (eds.): The triangle of microfinance: Financial sustainability, outreach, and impact, Baltimore and London: Johns Hopkins University Press: 19-45. 


\section{Appendix}

Table 4: Definition of Explanatory Variables for Sri Lanka

\begin{tabular}{|c|c|}
\hline Variable & Description \\
\hline Female head & Dummy variable, 1 if household is headed by a female, 0 otherwise \\
\hline Household size & Household size \\
\hline Married head & Dummy variable, 1 if household head is married, 0 otherwise \\
\hline $\begin{array}{l}\text { Ratio of ill household } \\
\text { members }\end{array}$ & $\begin{array}{l}\text { Ratio of ill household members in the previous } 12 \text { months to the total number of household } \\
\text { members }\end{array}$ \\
\hline Age & Age of the household head \\
\hline Age squared & Age of the household head squared \\
\hline No or primary education & Dummy variable, 1 if household has no or only primary education, 0 otherwise \\
\hline Secondary education & Dummy variable, 1 if household has secondary education, 0 otherwise \\
\hline Head is self- employed & $\begin{array}{l}\text { Dummy variable, } 1 \text { if household head is self-employed or contractual worker in either agriculture or } \\
\text { non-agricultural activities, } 0 \text { otherwise }\end{array}$ \\
\hline Head is unemployed & $\begin{array}{l}\text { Dummy variable, } 1 \text { if household head is not employed due to young or old age, disability, or similar } \\
\text { reasons, } 0 \text { otherwise }\end{array}$ \\
\hline Assets & $\begin{array}{l}\text { Assets (for Sri Lanka: motorcycle, bicycle, jewelry, refrigerator, sewing machine, electric iron, water } \\
\text { heater, fan, TV, DVD, radio, fixed phone, mobile phone, main source of drinking, toilet facility, } \\
\text { main source of lighting) owned by the household and was not purchased by a loan, index created by } \\
\text { factor analysis }\end{array}$ \\
\hline Quintile 1-5 & $\begin{array}{l}\text { Five asset index quintiles labeled as Quintile } 1 \text { to } 5 \text {, Quintile } 1 \text { is the poorest quintile and } \\
\text { Quintile } 5 \text { is the quintile of households with the highest asset endowment. } \\
\text { Dummy variables, } 1 \text { if household belong to the asset index quintile, } 0 \text { otherwise. (Quintile } \\
5 \text { functions as reference category) }\end{array}$ \\
\hline Land ownership & Dummy variable, if the household owns any land, 0 otherwise \\
\hline Remittance & $\begin{array}{l}\text { Dummy variable, } 1 \text { if household receives remittances from former household members who have } \\
\text { migrated, } 0 \text { otherwise }\end{array}$ \\
\hline Risk assessment & $\begin{array}{l}\text { Household's assessment of risk own risk situation (subjective exposure to health shocks, road or } \\
\text { work accidents, and economic shocks compared with neighbours, own rating of willingness to take } \\
\text { risks), index created by factor analysis }\end{array}$ \\
\hline Experienced & Dummy variable, 1 if household experienced the death of a household member in the last five years \\
\hline Death & $\begin{array}{l}\text { and this shock had serious consequences, i.e. household needed more than one month to recover, } 0 \\
\text { otherwise }\end{array}$ \\
\hline $\begin{array}{l}\text { Experienced } \\
\text { Illness }\end{array}$ & $\begin{array}{l}\text { Dummy variable, } 1 \text { if household experienced the illness of a household member in the last five } \\
\text { years and this shock had serious consequences, i.e. household needed more than one month to } \\
\text { recover, } 0 \text { otherwise }\end{array}$ \\
\hline $\begin{array}{l}\text { Experienced other severe } \\
\text { shock }\end{array}$ & $\begin{array}{l}\text { Dummy variable, } 1 \text { if household experienced a severe shock other than the previous described } \\
\text { shock in the last five years and this shock had serious consequences, i.e. household needed more } \\
\text { than one month to recover, } 0 \text { otherwise }\end{array}$ \\
\hline $\begin{array}{l}\text { Locational/Regional } \\
\text { dummies }\end{array}$ & $\begin{array}{l}\text { Sri Lanka: Dummy variables, } 1 \text { if household resides in the region, and } 0 \text { otherwise. Nine dummy } \\
\text { variables (Western, Southern, North Western, North, Central, Sabara, North Central, Uva and } \\
\text { Western region) are used in the analysis. Central region functions a reference category. }\end{array}$ \\
\hline
\end{tabular}

Source: Authors' illustration. 
Table 5: Multivariate Probit Results on the Type of Insurance for Sri Lanka (II)

\begin{tabular}{|c|c|c|c|c|c|c|c|c|c|}
\hline \multirow[t]{2}{*}{ Variable } & \multicolumn{3}{|c|}{ Life Insurance } & \multicolumn{3}{|c|}{ Health Insurance } & \multicolumn{3}{|c|}{ Other Insurance } \\
\hline & Coefficient & APEs & z-statistic & Coefficient & APEs & z-statistic & Coefficient & APEs & z-statistic \\
\hline Female head & -0.457 & -0.071 & -0.69 & 1.392 & 0.0006 & $2.45^{* * *}$ & -0.510 & -0.023 & -0.83 \\
\hline Household size & 0.141 & 0.029 & 1.18 & 0.191 & $6.90 \mathrm{e}-06$ & 1.34 & 0.338 & 0.029 & $2.31 * *$ \\
\hline Married Head & -0.313 & -0.068 & -0.59 & 0.864 & $8.55 e-06$ & 1.00 & -1.354 & -0.206 & $-2.63^{* * *}$ \\
\hline $\begin{array}{l}\text { Ratio of ill household } \\
\text { members }\end{array}$ & 0.246 & 0.054 & 0.27 & 0.151 & $4.94 \mathrm{e}-06$ & 0.16 & -0.040 & -0.002 & -0.09 \\
\hline Age & -0.165 & -0.028 & $-2.89 * * *$ & -0.211 & $-3.16 e-06$ & $-2.24 * *$ & -0.119 & -0.007 & -1.27 \\
\hline Age squared & 0.002 & 0.0003 & $3.01 * * *$ & 0.002 & $5.15 \mathrm{e}-08$ & $2.80^{* * * *}$ & 0.0008 & 0.00005 & 0.85 \\
\hline $\begin{array}{l}\text { Education of househol } \\
\text { head (base: tertiary } \\
\text { education) }\end{array}$ & & & & & & & & & \\
\hline $\begin{array}{l}\text { No or primary } \\
\text { education }\end{array}$ & 1.588 & 0.462 & $4.11^{* * *}$ & 2.749 & 0.014 & $3.16^{* * *}$ & -0.316 & -0.016 & -0.51 \\
\hline Secondary Education & 0.754 & 0.156 & $4.36 * * *$ & 1.801 & 0.0004 & $2.06^{* *}$ & 0.056 & 0.003 & 0.24 \\
\hline $\begin{array}{l}\text { Occupation of } \\
\text { household head (base: } \\
\text { formal } \\
\text { employee/employer) }\end{array}$ & & & & & & & & & \\
\hline Head is selfemployed & 0.575 & 0.103 & 1.56 & -1.099 & -0.00008 & $-2.87 * * *$ & -0.332 & -0.022 & -1.05 \\
\hline Head is unemployed & 0.243 & 0.050 & 0.75 & -1.945 & -0.00003 & $-3.41 * * *$ & -0.421 & -0.021 & $-1.64^{*}$ \\
\hline $\begin{array}{l}\text { Asset Index } \\
\text { Asset Quintiles (base: } \\
\text { the richest } 20 \% \text { ) }\end{array}$ & - & & - & - & & - & - & & - \\
\hline Quintile 1 & -3.019 & -0.269 & $-6.99 * * *$ & -3.497 & -0.0001 & $-4.39 * * *$ & -0.654 & -0.029 & -0.95 \\
\hline Quintile 2 & -2.689 & -0.247 & $-5.92^{* * *}$ & -3.982 & -0.0002 & $-3.62 * * *$ & -0.004 & -0.0003 & -0.01 \\
\hline Quintile 3 & -2.229 & -0.218 & $-6.48^{* * *}$ & -1.922 & -0.00003 & $-7.38^{* * *}$ & -0.409 & -0.020 & -0.62 \\
\hline Quintile 4 & -0.168 & -0.029 & -0.89 & -0.473 & $-6.91 e-06$ & $-2.67 * * *$ & 1.252 & 0.162 & $2.24^{* *}$ \\
\hline Land Ownership & 0.771 & 0.133 & $2.13^{* *}$ & -0.659 & -0.00004 & -0.64 & 0.395 & 0.020 & $2.04 * *$ \\
\hline Remittance & 0.362 & 0.083 & 0.50 & -1.329 & $-6.85 e-06$ & -1.24 & 2.098 & 0.504 & $1.68^{*}$ \\
\hline $\begin{array}{l}\text { Self risk assessment } \\
\text { Household's risk } \\
\text { experience (base: no } \\
\text { risk experience) }\end{array}$ & 0.014 & 0.003 & 0.08 & 0.333 & 0.00002 & $1.78^{*}$ & 0.040 & 0.003 & 0.33 \\
\hline Experienced death & 0.283 & 0.062 & 0.46 & -0.295 & $-4.17 \mathrm{e}-06$ & -0.55 & 0.817 & 0.097 & $1.96 * *$ \\
\hline $\begin{array}{l}\text { Experienced severe } \\
\text { illness }\end{array}$ & 0.152 & 0.031 & 0.47 & 0.880 & 0.0001 & 1.24 & -1.093 & -0.036 & -1.45 \\
\hline $\begin{array}{l}\text { Experienced other } \\
\text { severe risk }\end{array}$ & -0.913 & -0.147 & $-3.23 * * *$ & -0.687 & -0.00001 & -1.49 & -0.887 & -0.046 & $-2.18^{* *}$ \\
\hline Regional Dummies & Yes & - & - & Yes & - & - & Yes & - & - \\
\hline Est. correlation coeff. & $\varrho_{21}=0.166$ & & 1.23 & $\varrho_{31}=$ & .712 & $-7.54 * * *$ & $\varrho_{32}=-0.577$ & & $-3.91 * * *$ \\
\hline
\end{tabular}

Source: Authors' calculation.

Note: Results of the trivariate probit model are estimated by SML with 20 pseudorandom draws. t-statistics refer to the estimated coefficients and are based on robust standard errors. Average partial effects (APEs) are calculated with respect to the marginal probability of each type of insurance. The model also includes a constant. Sample size is $\mathrm{N}=330$ observations. The asterisks indicate level of significance: *** significant at 1 percent, ** significant at 5 percent, * significant at 10 percent. 